\title{
religion

\section{'This is Not the Holy Land': Gendered Filipino Migrants in Israel and the Intersectional Diversity of Religious Belonging}

\author{
VIVIENNE JACKSON*
}

\begin{abstract}
Social research has highlighted the positive outcomes of religious faith and practice for integration and belonging amongst migrants of different genders. However narratives of Filipino migrants in Israel suggest that religion, gender and belonging may not go hand-in-hand. By applying Anthias' intersectional framework of 'translocational positionality', a wider range of religious faith can be taken into account beyond gendered patterns amongst participants and activists in religious communities. Religious belief and gender intersect with other social locations, leading to the expression of complex orientations to belonging: where people believe they fit into the social order. Going beyond the categories of religion and gender to take in other intersections is essential in understanding the experiences of "non-organised" believers - and non-believers - as well as active religious participants.
\end{abstract}

\section{Keywords}

Belonging, intersectionality, migrant workers, Filipino, Israel, translocational positionality.

\section{Author affiliation}

Vivienne Jackson recently completed her PhD in the School of Sociology, Politics and International Studies, University of Bristol (UK).

* Correspondence: 214 Brettenham Road, Walthamstow, London, E17 5AY, United Kingdom. E-mail: jacksonvivienne@gmail.com

This work is licensed under a Creative Commons Attribution License (3.0)

Religion and Gender | ISSN: 1878-5417 | www.religionandgender.org | Igitur publishing 


\section{Introduction}

This article uses Anthias' intersectional framing of 'translocational positionality' to depict multiple ways that religion and gender form - and do not form part of resituated experiences of belonging for Filipino migrants in Israel. Social research has recently highlighted the positive outcomes of religious faith and practice for integration and belonging amongst migrants, often along gendered lines. However, narratives of Filipino migrants in Israel suggest that religion, gender and positive forms of belonging may not always go hand-in-hand. In order to further enrich depictions of the sociological relationships between religion and gender amongst migrants, researchers need to pay attention to additional social locations and processes. Current political environments and discourses in the West may promote a tendency in migration studies to replace historical obsessions with ethnic and national identities with fixed religious identities, ${ }^{1}$ in particular gendered religious identities. ${ }^{2}$

Rather than use the term 'identity', given the multiple criticisms levied at the latter, ${ }^{3}$ translocational understandings of 'belonging' offers a relational and processual alternative that recognizes shifts and contradictions in people's sense of social selfhood and collective identifications, arising through the dynamic social locations in which people are situated. ${ }^{4}$ By using the term belonging in this way, our accounts of how religion and gender form part of migrants' sense of social self can become increasingly subtle as we begin to include in our analyses, firstly, those who are not part of organized religious communities, and secondly, a range of other social locations such as class, nationality and sexuality that may bear significantly upon gender and religion.

\section{Allowing Religion and Gender to Emerge in Tandem with Other Factors}

Floya Anthias has devised the intersectional framing of translocational positionality to investigate complex kinds of belonging and not-belonging amongst

\footnotetext{
1 A. Wimmer and N. Glick Schiller, 'Methodological Nationalism and Beyond: Nation-State Building, Migration and the Social Sciences' in Global Networks 2:4 (2002), 301-334; N. Jeldtoft and J.S. Nielsen, 'Introduction: Methods in the Study of Non-organized Muslim Minorities' in Ethnic and Racial Studies 34: 7 (2011), 1113.

2 See B. Krondorfer and S. Hunt, 'Introduction: Religion and Masculinities - Continuities and Change' in Religion and Gender 2:2 (2012), 201; A. Höpflinger, A. Lavanchy and J. Dahinden, 'Introduction: Linking Gender and Religion' in Women's Studies 41 (2012), 625-626.

3 R. Brubaker and F. Cooper, 'Beyond Identity' in R. Brubaker (ed.), Ethnicity Without Groups, Cambridge MA: Harvard University Press 2004, 28-63; R. Handler, 'Is "Identity" a Useful Cross-Cultural Concept?' in J. Gillis (ed.), Commemorations: The Politics of National Identity, Princeton NJ: Princeton University Press, 27-40; F. Anthias, '“Where Do I Belong?" Narrating Collective Identity and Translocational Positionality' in Ethnicities 2:4 (2002), 491-514.

4 Anthias, "'Where Do I Belong", 495; N. Yuval Davis, The Politics of Belonging: Intersectional Contestations, London: Sage 2011.
}

Religion and Gender vol. 3, no. 1 (2013), pp. 6-21 
migrants. ${ }^{5}$ The problem with the conceptual use of identity, she argues, is that the term implies fixed and primary social locations in which a person or group appears to be anchored. However, intersectional feminist theorists have demonstrated that individuals are constituted through multiple and mutually embedded social locations, rather than any single social structure or prevailing dyad. ${ }^{6}$ While social scientists may need at times to separate out different fields of structural power or action (such as gender or religion) in order to talk about them analytically, such ontological categories are embodied in the concrete social individual through complex, entwined social processes. ${ }^{7}$ Different structural factors have particular salience for certain individuals depending on context, time and place.

Migrants in particular are often positioned in numerous, complicated social emplacements over time and space due to their diverse 'dislocations and relocations'. 'Translocations' refers to this complex situatedness in multiple locations: socio-structural, geo-political and historic-biographical. Locations might include, as non-exhaustive examples: class; gender; ethnicity; religion; nationhood; destination state(s) and city location(s); cohort of migration; specific forms of biopolitical migration governance; ${ }^{9}$ and social life cycle stages. 'Positionality' describes the points in people's narratives and social practices whereby they take up positions that show their understanding of and emotional orientation to their own place within that social order: where they feel they belong. Accordingly, the concept of belonging employed in this article helps researchers represent more elusive, more transient and more nuanced senses of social self than have sometimes been implied by focusing in on certain categories of identity analysis from the outset.

There are a number of advantages for the exploration of links between religion and gender through this understanding of belonging. Firstly, this intersectional approach is interested in what collective affiliations and repudiations matter to people in daily life as much as in restricted (and often rhetorically charged) public spheres. Secondly, by focusing on positionalities of belonging,

\footnotetext{
5 F. Anthias, '“Where Do I Belong?"'; F. Anthias, 'Belongings in a Globalising and Unequal World: Rethinking Translocations' in N. Yuval Davis, K. Kannabiran, and U. Vietan (eds.), The Situated Politics of Belonging, London: Sage 2006, 17-31; F. Anthias, 'Gender, Ethnicity and Class: Reflecting on Intersectionality and Translocational Belonging' in The Psychology of Women Review 9:1 (2007), 2-11; F. Anthias, 'Thinking Through the Lens of Translocational Positionality: An Intersectionality Frame for Understanding Identity and Belonging' in Translocations 4:1 (2008), 5-20.

6 F. Anthias and N. Yuval-Davis, 'Contextualising Feminism: Gender, Ethnic and Class Divisions' in Feminist Review 15 (1983), 62-75; K. Crenshaw, 'Demarginalising the Intersection of Race and Sex: A Black Feminist Critique of Antidiscrimination Doctrine, Feminist Theory and Antiracist Politics' in University of Chicago Legal Forum 139 (1989), 139-167; P. Hill Collins, 'The Ties That Bind: Race, Gender and US Violence' in Ethnic and Racial Studies 21:5 (1998), 917-938; L. McCall, 'The Complexity of Intersectionality' in Signs: Journal of Women in Culture and Society 30:3 (2005), 1771-1800.

7 N. Yuval-Davis, 'Intersectionality, Citizenship and Contemporary Politics of Belonging' in Contemporary Review of International Social and Political Philosophy 10:4 (2007), 562.

8 F. Anthias, '"Where Do I Belong?"', 499.

9 J. Tyner, Made in the Philippines: Gendered Discourses and the Making of Migrants, Oxford: Routledge 2004; M. Asis, 'Caring for the World', 27.
} 
attention is brought not only to the contexts where people talk about religious belonging/not-belonging, but, importantly, when they do not. When is religion not important for different men and women migrants who are otherwise religious as they negotiate their host societies? At times people may indicate a strong sense of belonging to a particular denomination in a gendered way; at another time, such expressions may be ambivalent or entirely absent, and researchers must be attentive to both presences and absences. Thirdly, the approach requires considering how religion and gender are linked dynamically to other social locations, such as class, age, and sexuality. For example, gender is a relational and situational set of practices and understandings, ${ }^{10}$ but not only so in terms of gender itself. Gendered religious practices relate to the processes of other social structures that situate social beings.

Such emergent connections and disconnections of belonging during research are profoundly exciting departures for thinking about the links between migration, religion and gender. While the scope of the following analysis in this article cannot fully elaborate upon its implications for gender studies and intersectional theory more widely, the narratives of the featured participants give a strong flavour of the ways in which paying attention to other intersections can enrich our understanding of religion and gender. The analysis has particular relevance for the many gendered studies of migration that have recently turned their attention to religion. ${ }^{11}$ My study, based on 52 narrative interviews and wider participant observation carried out in 2008-2009 explores positionalities of belonging amongst Filipino men and women working in Israel, mainly in the cities of Tel Aviv and Haifa. The interviews took place against a backdrop of rising anxiety amongst Filipino migrant workers, particularly undocumented workers, as a deportation drive was instigated (see below).

\section{Migrant Workers, Care-givers and Israel}

In Israeli cities, particularly Tel Aviv, numerous migrant evangelical Christian communities have been established since the official import of migrant workers began in the early 1990s. Contract migrant workers were first hired en masse to fill secondary sector agricultural and construction roles previously held by Palestinians from the Occupied Territories (excluded from Israel as a political consequence of the First Intifada, 1987-1991). ${ }^{12}$ Subsequently, the paid domestic care sector for elderly and disabled people in Israel has become staffed largely by temporary contract migrant caregivers, enabling families to afford 24-hour care within the now-marketized care regime. ${ }^{13}$ Today Israel is regularly in the

\footnotetext{
${ }^{10}$ P. Pessar and S. Mahler, 'Transnational Migration: Bringing Gender In' in International Migration Review 37:3 (2003), 12-46.

11 See for example: G.T. Bonifacio and V.S.M. Angeles (eds.), Gender, Religion and Migration: Pathways of Integration, Lanham: Lexington 2010.

12 D. Bartram, 'Foreign Workers in Israel: History and Theory' in International Migration Review 32:2 (1998), 303-325; I. Drori, Foreign Workers in Israel, Albany NY: State University of New York Press 2009, 5-11.

${ }^{13}$ A. Kemp and R. Raijman, Migrants and Workers: The Political Economy of Labor Migration in Israel, Jerusalem: Van Leer Institute 2007, 112 (Hebrew).
}

Religion and Gender vol. 3, no. 1 (2013), pp. 6-21 
top five industrialized states that employ migrant workers as a proportion of the total working population. ${ }^{14}$ The arrival of many thousands of non-Jews, albeit ostensibly as temporary contract workers, marks a significant watershed for the ius-sanguinis, Jewish-only Israeli migration regime.

Filipino migrant workers enduringly constitute the majority of caregivers in Israel. Official Israel statistics estimate around 26,100 Filipinos currently in Israel who entered from 1995 to $2011 .{ }^{15}$ While most Filipinos are documented, a significant minority of workers have overstayed their work visa. ${ }^{16} \mathrm{It}$ is impossible to give accurate occupational figures, not least because Israeli official statistics about undocumented populations appear to be biased towards understatement. ${ }^{17}$ Anecdotally, many longer-term Filipino migrants who are no longer documented have left caregiving for 'live-out' work, such as cleaning. Migrant caregivers in Israel experience similar problems to those detailed in the impressive research literature that tackles migrant domestic employment in various regions of the world: illegal migration entry practices, inadequate rights enforcement at work, disciplinary micro-controls in employer homes, neglect, sexual harassment, other abuse. ${ }^{18}$ There are also specific difficulties and opportunities that result from the particular Israeli social, political and urban environments for migrant workers. Day-to-day Israeli state practice towards undocumented migrant workers can be unpredictable, and sometimes harsh. This is illustrated in periods of deportation, most recently under the auspices of the dedicated Unit Oz (2009 to date).

Yet official exclusion from citizens' (rather than workers') rights, negative discourses about migrant workers and everyday discrimination are slightly countered by other everyday factors. There are positive strains of popular discourse about

\footnotetext{
${ }^{14}$ N. Wurgaft, Open Up - Police! Migrant Workers in Israel, Tel Aviv: Am Oved 2006, 25 (Hebrew); Kemp and Raijman, ibid., 47.

15 Israel Central Bureau of Statistics (2012), 'At the End of 2011: 111,000 Foreign Workers who Entered with Work Permits and 92,000 who Entered as Tourists' (Hebrew), 3. http://www1.cbs.gov.il/reader/newhodaot/hodaa_template.html?hodaa $=201220194$ (accessed 15/12/2012).

${ }^{16}$ Israel Central Bureau of Statistics (2012), 'At the End of 2011', 4. Separate figures for Filipino overstayers are not provided.

17 B. Kalir, Latino Migrants in the Jewish State: Undocumented Lives in Israel, Bloomington and Indianapolis: Indiana University Press 2010, 46.

${ }_{18}$ B. Anderson, Doing the Dirty Work? The Global Politics of Domestic Labour, New York, Zed 2000; P. Hondagneu-Sotelo, Domestica: Immigrant Workers Cleaning and Caring in the Shadows of Affluence, Berkeley, University of California Press 2001; R. Salazar Parreñas, Servants of Globalization: Women, Migration and Domestic Work, Stanford CA: Stanford University Press 2001; B. Ehrenreich and A.R. Hochschild (eds.), Global Women: Nannies, Maids, and Sex Workers in the New Economy, London: Granta 2002; M. Asis, 'Caring for the World: Filipino Domestic Workers Gone Global' in S. Huang, B. Yeoh and N. Abdul Rahman (eds.), Asian Women as Transnational Domestic Workers, Singapore: Marshall Cavendish 2005, 21-53; C. Chin, 'Walls of Silence and Late Twentieth Century Representations of the Foreign Female Domestic Worker: The Case of Filipina and Indonesian Female Servants in Malaysia' in International Migration Review 31:2 (1997), 353; S. Huang and B. Yeoh, 'Ties that Bind: State Policies and Migrant Female Domestic Helpers in Singapore' in Geoforum 27:4 (1996), 479-449; N. Constable, 'Sexuality and Discipline among Filipina Domestic Workers in Hong Kong' in American Ethnologist 24:3 (1997), 539-558.
} 
non-Jewish migrants. ${ }^{19}$ Some Filipino workers have genuinely warm links with their employers. ${ }^{20}$ A small number, overwhelmingly women, have residency or citizenship based on marriage and common-law relationships with Israeli citizens. Some migrant workers have started Israeli-based families. In 2006 and again in 2010 the Israeli government regularized the status of some migrant workers' children, giving them eventual Israeli citizenship on legal maturity and the right for their nuclear family present in Israel to stay with them. ${ }^{21}$ Different Israeli NGOs provide support and advocacy on specific migration issues. There have been successes on a case-by-case basis in the courts in establishing some migrants' 'right to be in Israel rather than the rights associated with de facto presence'.22

Israeli city environments for migrant workers differ. Tel Aviv's municipality has provided support services for migrants, and certain hitherto Jewish schools actively welcome the children of migrants. Haifa, in contrast, has no ostensible official migrant worker provision. Yet migrants in both cities have marked their presence in neglected areas. The stigmatization of Tel Aviv's New Central Bus Station has enabled the establishment of migrant businesses, cafes, bars and churches there. ${ }^{23}$ On a much smaller scale, some migrant churches and shops are located in the Hadar neighbourhood, Haifa. Despite the apparently unpromising environment in Israel for permanent migration, some migrant workers have started to settle there.

\section{Migrant Worker Churches in Israel: Their Place in Research}

Recent social research has revealingly investigated ways in which religion can contribute to a changing sense of social and political belonging amongst migrant workers taking up working-class jobs at destination. ${ }^{24}$ This ethnographic focus has helped to steer migration studies away from assumptions that national or ethnic identities are of paramount importance to migrants themselves. ${ }^{25}$

\footnotetext{
19 I. Drori, Foreign Workers, 103.

${ }^{20}$ C. Liebelt, "'We are the Jews of Today": Filipino Domestic Workers in Israel and the Language of Diaspora' in Hagar: Studies in Culture, Polity and Identities 8:1 (2008), 7.

${ }^{21}$ Each regularization stipulates a number of conditions for residency that will qualify a child, such as Hebrew language, integration in school and/or continuous years in Israel.

${ }^{22}$ G. Mundlak, 'Litigating Citizenship beyond the Law of Return' in S. Willen (ed.), Transnational Migration to Israel in Global Comparative Context, Lanham MD: Lexington Books 2007, 64.

${ }^{23}$ L. Amdur and M. Epstein-Pliouchtch, 'Architects' Places, Users' Places: Place Meanings at the New Central Bus Station, Tel Aviv' in Journal of Urban Design 14:2 (2009), 152.

${ }^{24}$ N. Glick Schiller, A. Çaglar and T. Guldbrandsen, 'Beyond the Ethnic Lens: Locality, Globality and Born-Again Incorporation' in American Ethnologist 33:4 (2006), 612-633; N. Kibria, 'Muslim Encounters in the Global Economy: Identity Developments of Labour Migrants from Bangladesh to the Middle East' in Ethnicities 8:4 (2008), 518-535; P. Levitt, 'Religion as A Path to Civic Engagement and Civically-Infused Religion' in Ethnic and Racial Studies 31:4 (2008), 766-791.

${ }^{25}$ A. Wimmer and N. Glick Schiller, 'Methodological Nationalism and Beyond: Nation-State Building, Migration and the Social Sciences' in Global Networks 2:4 (2002), 301-334.
} 
Migrant religious beliefs and practices may supplant, challenge or transform official policies and informal practices that initially limit their integration. ${ }^{26}$ Working in this genre, sociologists and anthropologists in Israel have particularly shown that evangelical Christian labour migrants have developed a positive interpretative framework for their migration situation. This is despite the ethnically/religiously exclusive Israeli migration regime and the purported temporariness of contract migration to Israel. ${ }^{27}$ The use of the term 'evangelical' here is intentionally broad, incorporating all intentionally proselytizing nonCatholic church denominations found in Israel. The permeable and shifting boundaries between evangelical communities make elusive a precise mapping of the migrant Christian landscape in Israel. ${ }^{28}$ As elsewhere, migrant evangelical communities in Israel provide 'spiritual relief, a social network, a feeling of belonging, and some practical aid such as free Hebrew language lessons. ${ }^{29}$

Strikingly, some evangelical migrant worshippers in Israel may make political and social claims of belonging to Israel as a state, often grounded in Christian Zionist political support for the Israeli state, prevalent in some evangelical theologies. ${ }^{30}$ Migrant evangelical churchgoers may draw from experiences in Israel to bear Zionist witness with communities back home or transnationally. ${ }^{31}$ At the same time, they may argue for Israeli citizenship to be extended to non-Jews who support Israel. Such claims of belonging are not only discursive but also performative: through incorporating Jewish ritual at churches, ${ }^{32}$ engaging in religious tourism ${ }^{33}$ and learning to perform Israeliness in daily life. ${ }^{34}$ Caregivers in particular may encounter views and stories of employers who are, for example, Holocaust survivors. ${ }^{35}$ In this way, the embodied labour of evangelical Filipino migrants with elderly Jews comes to embody their reli-

\footnotetext{
${ }^{26}$ T. Modood, 'Britishness out of Immigration and Anti-Racism' in B. Chandra and S. Majahan (eds.), Composite Culture in a Multicultural Society, New Delhi: Longman 2007, 32-49.

27 Non-Jewish spouses and partners of Israeli Jews may gain citizenship, for example. There have been other rare cases of citizenship granted to non-Jews.

${ }^{28}$ R. Raijman and A. Kemp, 'Consuming the Holy Spirit in the Holy Land: Evangelical Churches, Labour Migrants and the Jewish State' in Y.S. Carmeli and K. Applebaum (eds.), Consumption and Market Society in Israel, Oxford: Berg 2004, 169.

${ }^{29}$ B. Kalir, 'Finding Jesus in the Holy Land and Taking Him to China: Chinese Temporary Migrant Workers in Israel Converting to Evangelical Christianity' in Sociology of Religion, 70:2 (2009), 130-156; see also C. Liebelt, Caring for the 'Holy Land': Filipina Domestic Workers in Israel, New York and Oxford: Bergahn Books 2011; Sabar, G., "The Rise and Fall of African Migrant Churches; Transformations in African Religious Discourse and Practice in Tel Aviv", in S. Willen, Transnational Migration to Israel in Global Comparative Context, Lanham MD: Lexington Books 2007, 185-202.

${ }^{30}$ Kalir, Latino Migrants in the Jewish State, 7; Raijman and Kemp, 'Consuming the Holy Spirit in the Holy Land, 163-183.

${ }^{31}$ Kemp and Raijman, 'Christian Zionists', 309.

32 Raijman and Kemp, 'Consuming the Holy Spirit', 175.

33 Liebelt, Caring for the 'Holy Land', 182.

${ }^{34}$ Kalir, Undocumented Lives, 6.

35 Liebelt, 'We are the Jews of Today', 113; C. Liebelt, "On Sentimental Orientalists, Christian Zionists, and 'Working Class Cosmopolitans': Filipina Domestic Workers" in Journeys to Israel and Beyond' in Critical Asian Studies 40:4 (2008), 567-585.
} 
gious and political purpose in Israel. Often such experiences of belonging are presented as highly gendered, given the numerical dominance of Filipino women migrants as both caregivers and worshippers. Evangelical caregivers may also draw parallels between their situation and those of Jews facing persecution in the past. ${ }^{36}$

\section{Too Much Religion and Gender?}

The illuminating research above reveals radical reconstructions of political and social belonging amongst evangelical migrants in Israel. However, the predominant focus on organized evangelical Christianity, and the practical concentration in particular research cases on gender conceptualized as religious communities formed largely of women, is perhaps symptomatic of the need to look beyond visibly organized religious participants as recruitment sites within migration studies.

There are indeed proportionately more evangelical members and conversions among the total Filipino population in Israel compared to the domestic population in the Philippines. This may be due to, firstly, the attraction of Israel for re-baptized, pro-Israeli Christians ${ }^{37}{ }^{37}$ secondly, many Filipino migrants to Israel are middle-class migrants, highly represented in the domestic Filipino evangelical population. There is a mixture of charismatic and non-charismatic communities. Some movements, such as 'Jesus is Lord' (JIL) are churches of Filipino origin that have developed branches worldwide, partly through Filipino migration. ${ }^{38}$ Other Filipino evangelical Christians belong to global movements such as the Baptist Church. While some churches are established and easy to locate, others are tiny, hosted in overseas workers' flats. Evangelical Christian Filipinos in Israel, then, constitute a patchwork of differentiated worship communities.

All this said, most Filipino migrants in Israel, identify in some way as Catholic, not evangelical Protestants. ${ }^{39}$ Furthermore, there are some other smaller Filipino religious groups, such as Jehovah's Witnesses, and some non-churchgoing Christians. Jeldtoft and Nielson's critique that contemporary research with Muslims focuses too strongly upon their public and political life rather than private and vaguer senses of religious belonging is of wider relevance..$^{40}$ Certainly, when the most visibly religious people come to dominate research, it may obscure other ways in which non-organized but religiously self-affiliating people feel that they belong to their religious grouping, and what that means in their new migration environment. However, there is a further problem. By only listening

\footnotetext{
${ }^{36}$ Liebelt, 'We are the Jews of Today'.

37 Liebelt, 'On Sentimental Orientalists', 577.

38 Liebelt, Caring for the 'Holy Land', 168.

39 Philippines Embassy in Israel, 'Profile of the Filipino Community in Israel', www. phillipine-embassy.org.il/filipino-community/profile-of-the-filipino-community (accessed 21/11/2011).

40 Jeldtoft and Nielsen, 'Introduction: Methods in the Study of Non-organized Muslim minorities', 1113.
} 
out for the connections between gender and religion, even in the private or everyday spheres, we run the ongoing risk of depicting certain migrant categories as one-dimensional collectivities whose notions of belonging are fixed around a single self-categorization or a dyad of social structures, rather than multiple ideological collective entities. Religious categories of self-ascription and understanding may rise and fall in importance for particular migrants and migrant groups according to context, space and time, giving way on occasion to other priorities, and other senses of social selfhood. ${ }^{41}$

Further, studying religion and gender as a dyad can lead to a tendency to homogenize the links between them in ethnographic depictions of certain migrant men and women. ${ }^{42}$ Amplifying particular social categories to the detriment of others is of course common across different social science disciplines. In fact, it is sometimes analytically necessary and important to foreground particular conceptual domains and aspects of experience, and not all social locations are felt equally by those positioned through them. However, despite growing recognition of the importance of multiple social locations in shaping belonging and experience, certain social locations - even in intersectional work - tend to be given priority, depending on the tendencies of certain research traditions. ${ }^{43}$ The academic exploration of links between religion and gender in the construction of belonging requires particular caution in contemporary, neo-liberal times to avoid echoing the presumption by (Western) governments that religion is self-evidently central to migrants and minorities, and that gendered religious practices are the key site of difference between majorities and minorities. Such ideas contribute to the portrayal of Muslims, and perhaps other categories, as a legitimate target for securitization. ${ }^{44}$

Nonetheless, the important recognition in studies of religion and gender that the two are mutually embedded in lived experience ${ }^{45}$ has important and promising implications for feminist and critical scholarship that aspires to diversify the representation of gender and religion. This recognition of embeddedness can draw our attention to the mutually implicated ways that other aspects of belonging come to the fore for certain men and women, even as these too gesture towards religious belief and practice. Certainly for migrant Filipino women globally, where they feel they belong is highly inflected by ideas of class and hopes of social mobility. ${ }^{46}$ In the narratives below, the relationships evoked

${ }^{41}$ Cf. R. Brubaker, M. Feischmidt, J. Fox and L. Grancea, Nationalist Politics and Everyday Ethnicity in a Transylvanian Town, Princeton NJ: Princeton University Press 2006, 15.

${ }^{42}$ C. Thun, 'Norwegianness as Lived Citizenship: Religious Women doing Identity Work at the Intersections of Nationality, Gender and Religion' in Nordic Journal of Religion and Society 25:1 (2012), 20-21; Bonifacio and Angeles (eds.), Gender, Religion and Migration. ${ }^{43}$ M. Brown, 'Gender and Sexuality 1: Intersectional Anxieties' in Progress in Human Geography 36:4 (2012), 541.

44 Yuval Davis, The Politics of Belonging, 138; Jeldtoft and Nielsen, 'Non-organized Muslims', 1114.

${ }^{45} \mathrm{U}$. King and T. Beattie, Gender, Religion and Diversity. Cross-Cultural Perspectives. London/New York: Continuum 2004, 8.

${ }^{46}$ See P. Gardiner Barber, 'No/ma(i)ds: Silenced Subjects of Philippine Migration' in M. Achino-Loeb (ed.) Silence: The Currency of Power, New York: Berghahn Books 2006, 95; P. Gardiner Barber, 'Contradictions of Class and Consumption: When the Commodity is Labour' in Anthropologica 46:2 (2004), 203-218. 
in narratives between religion, gender and other social processes such as class express more nuanced ways in which women and men migrants construe how they belong to their religion, and also the ways in which their religion further affects where else they feel they belong in the social order.

\section{The Diversity of Belonging with Reference to Religion}

It is significant from the outset that social class as an indicator of belonging was a much more significant narrative theme amongst participants than religion. Nonetheless, religion certainly framed overt positionalities of forms of belonging - either to religious communities or configuring a place in Israel for a smaller number of participants, with 28 of 52 participants referencing religious beliefs and practices as a central part of their life story. Three different women here (Hannah, Velma and Ladonna), all evangelical Christians, provide a vital comparison. Each evokes, firstly, a sense of belonging to their religious community, and secondly certain senses of belonging in Israel informed by their religious beliefs. However, each narrative points to the importance of particular intersections and specific kinds of gendered and religious experience for the individual women in shaping the divergent content of their sense of belonging.

Hannah's sense of belonging chimes with that uncovered in previous research in Israel. She does not deviate from applying a religious lens upon her migration experiences in Israel. A documented resident for seven years, she is a widow, earning money to put her children through university in the Philippines. She briefly discusses her former life while consistently emphasizing biographical anecdotes and religious doctrines that express her current Christian purpose in and entitlement to stay in Israel: to bring salvation in Jesus to Jews:

There was a woman coming to us, her daughter was with cancer [...] I prayed for her, and she started crying, "I don't know what I feel when you start praying for me, it seems there was fire coming." ... And when I passed by to her house, I asked "How is your daughter", Ima? ${ }^{47}$ "Oh, she's okay now." So amazing, God's work with Israeli people. And we want to minister to the people of Israel. ... Psalms 22, Verse 6 says, "Pray, peace for Jerusalem, those who pray for them will be secured, will be loved by God." (Hannah)

In contrast, Velma's narrative points to complex locations over extended time rather than a predominant engagement with evangelical religious interpretation. A middle-class office manager in the Philippines, Velma arrived with her husband in Israel for working-class work in 1987, preceding (and prompting) the official importation of Filipino caregivers. She uses everyday examples of life in Israel that have led her to feel that she has, in many ways, become Israeli. Certainly, God's spectacular work is confirmed to her on occasion: Velma and her family witnessed Iraqi Scud missile attacks in Tel Aviv during the Persian Gulf War of 1991, an experience that she saw as evidence of God's support for Israel:

${ }^{47}$ Hebrew=Mother (courtesy term).

Religion and Gender vol. 3, no. 1 (2013), pp. 6-21 
Israelis said [to Velma and her husband]: 'Are you not afraid that you are going home?' ... We said: "The God of Israel is protecting Israel, why should you be afraid?" (Velma)

However, it is the everyday comfort and success that she perceives in daily life and motherhood in Tel Aviv that equally grounds her sense of belonging in Israel. She has lived happily amongst Jewish Israeli neighbours, rather than in the migrant neighbourhood of Neve Sha'anan. For Velma, her Israel-born son has been successful at his Tel Aviv school, and she is involved in municipallysupported activities such as Hebrew lessons and a migrant women's group. These routines weave Velma's class aspirations for family mobility that are such a critical (and sometimes overlooked) part of Filipino migration subjectivities, together with her 'at-home-ness' in her parts of Tel Aviv.

Some three years ago, [her son] was one of the representatives at the [Israeli] Mathematics Olympiada. I was so proud of him. So proud of him. He said: "Mummy, if I don't make it, will you be sad?" I said, "No, no not at all, this is an experience, it will be a great experience for you, and not all are given a chance like you," I said. (Velma)

Nevertheless, her sense of belonging in Israel is qualified, despite her religious belief and maternal satisfaction. Velma feels that life in Israel can never be certain for migrant workers, and indeed her husband was deported in 2005 (he later returned and the family became regularized under the terms for some families of children described earlier). This experience, plus her Zionist theology, means she does not feel entitled to a place in Israel at the same level of citizenship as Jews. While she looks down on Russian and Ethiopian Jewish migrants, she believes their claim to belong to be stronger than hers: ${ }^{48}$

It's not the Tel Aviv that I knew before. You could walk around without worry. Now there are shoplifters here, there are snatchers ... It's really weird, ever since the Russians and the Ethiopians came, Israel became different. But they are Jews, what can I say? They need to come back. (Velma, my emphasis)

To understand the links between Velma's sense of gendered self and her religious belonging in the context of Israel means taking in various intersections manifest in her narrative: her religious belief (the interpreted tenets of her particular evangelical outlook) and religious community (her everyday practical involvement with her community); secular activities; uncertain migration status; city-location; class aspirations; and gendered parenting.

Alternatively, Ladonna's narrative demonstrates that evangelical Christianity is not solely associated amongst participants with claims of personal belonging in Israel. Ladonna is deeply involved in the Jesus is Lord (JIL) church in Haifa. She held deep affection for an orthodox Jewish employer who then died. The more positive interpretations of relations between Jews and Christians found in some forms of Christian Zionism had been embedded for her in everyday experiences of affection and cultural learning:

${ }^{48}$ Cf. Z. Rosenhek, 'The Politics of Claims-Making by Labour Migrants in Israel' in Journal of Ethnic and Migration Studies 25:4 (1999), 575-595. 
Ladonna: They [the family] are religious people so on Shabbat they are setting the table, putting the food in the oven to make it hot, before, before...I learned everything, that before the Shabbat you have to turn on all the lights, and... mmm...it has, they have, what do you call it? 'Shabbat Shaon'.49 ... It's a wonderful experience to work with this kind of people.

\section{$[\ldots]$}

V: Why did you move?

L: It was very sad. She died. [It was] a very hard time because [cries] it's very hard. It's like I lost my own mother.

However, Ladonna's delight at being in the Holy Land, her evangelical world view and her close relationship with an employer have not led her to reevaluate herself to be either a Christian Israeli or to claim belonging beyond a temporary comfort and support for Israel. In fact, she is headed onwards to Canada. Israel is rightly conceived as a 'stepping stone' country for many Filipino migrants: one stop amid many consecutive placements. ${ }^{50}$ The cultural weight of the entrenched Philippine migration industry, urging migrants to maximize their economic 'opportunities' in the global economy, has influenced Ladonna. ${ }^{51}$ Ladonna's gendered class logic emanating from in the Philippines - to migrate strategically to maximize the benefits for themselves and their families back home - leads her to pursue further overseas work. Ladonna's attachment to her religious experience and special employer in Israel has provided her with a sense of meaning and inclusion during her temporary contract. She is perhaps akin to a 'vernacular cosmopolitan'.52 Here, a recognition of the importance of class as it intersects with religion and gender for Ladonna is vital to understand how she conceptualizes her religious belonging, and her wider sense of social belonging within and without of Israel.

\section{Gender, Religion and Crises of Belonging}

Margold has shown compellingly how Filipino Ilocano men, having come from fluid cultural masculinities in environments of relative gender equality, experience themselves to be socially suspended men in Saudi Arabian work camps. ${ }^{53}$ Rather differently, Filipino male participants here tended to experience a com-

\footnotetext{
${ }^{49}$ A clock timer that allows Orthodox Jews to comply with Jewish religious law's restrictions upon use of electricity on the Sabbath.

50 Liebelt, 'We are the Jews', 571.

51 Tyner, Made in the Philippines, 47; P. Gardiner Barber, 'The Ideal Immigrant? Gendered Class Subjects in Philippine-Canada Migration' in Third World Quarterly 29:1 (2008), 1268.

52 P. Werbner, 'Understanding Vernacular Cosmopolitanism' in Anthropology News 47:5 (2006), 7-11.

53 J. Margold, 'Global Disassembly: Migrant Masculinity in the Transnational Workplace' in Masculinities 2:3 (1994), 18-36.
} 
bination of restrictions and continuity upon conventional forms of masculinity. Not one male participant had ever worked or trained in a caring or analogous profession before reaching Israel, reflecting the prevailing notion in the Philippines that professional caring is women's work. This contrasted with 15 women trained in care-focused work. More men than women - particularly middle-class men - talked about a difficult 'adjustment period' when starting work in Israel (although some came to value caregiving).

However, familiar forms of masculine sociability could continue on weekends given the unusual mixed-gender environment amongst migrant Filipinos in Israel. In contrast to women in my sample, a small number of evangelical men portrayed a hedonist existence during free-time in Israel. These men depicted their hard partying as a crisis specific to men resulting from migration resolved through evangelical religious belonging and activism. ${ }^{54} \mathrm{Again}$, however, exactly how these men felt they belonged to their religious community and depicted their place in Israel was profoundly shaped by other social locations, such as age, migration status and city residence. Gary, for example, framed his religious conversion as a rejection of sinning masculinity. Yet importantly his narrative indicated that in his view he had also reached a point in his social life cycle where promiscuity had become alienating, and he had successfully found a lifepartner within his church. Gary's narrative also contains a fascinating twist that demonstrates that city locations may be key intersections that modulate the ideological terms of religious belonging. Based in Haifa, Northern Israel, Gary had on occasion worshipped in the nearby town of Usfiya where a Christian community of evangelicals from Jewish, Palestinian and foreign backgrounds was located. In sharp distinction to the anti-Arab/Muslim/Palestinian discourse proffered by some Christian Zionist thought, Gary's sense of belonging is tied into a pacific religious journey:

I...took [my Jewish employer] to Usfiya where Arabs and Jews gather together to worship.... [W]e decided one day to visit it, and he was surprised because of the message, and the singing. Just imagine, Arab and Jew, gathered together. (Gary, evangelical)

\section{Religion, Gender and Not-belonging}

Taking into account other intersections alongside religion and gender also enables greater sensitivity to those moments where people stop feeling they belong, whether to a religious community or to other ideological collectivities. Many people talked about the religious fulfilment gained through physical presence in the 'Holy Land' and visiting biblical sites in Israel. However, concepts such as the 'Chosen People' and the Holy Land could come to underscore the profanity of everyday life in Israel. This could be linked to perceived morally deficient social norms in Israel, Israel's incessant involvement in military conflict, as well as problems encountered during caregiving:

${ }^{54}$ G.T. Cruz, "'It Cuts Both Ways": Religion and Filipina Domestic Workers in Hong Kong' in G.T. Bonifacio and V.S.M. Angeles (eds.), Gender, Religion and Migration: Pathways of Integration. Lanham: Lexington 2010, 17-36. 
When I reached here, when I meet some of the people killing each other, Hizbullah and some Hebrews fighting each other...because I already planned in my head and my heart that all the Israeli people are good people [pauses] I said to myself: "This is not the Holy Land." (Marissa, former evangelical)

It was a shock when I came. Because [Jews] are religious, I thought they are God-fearing, I thought this is a holy nation, but when I came here I saw a lot of weakness. (Christy, Baptist)

Joanna, a Catholic Zionist, and former university secretary, was in a relationship with an Israeli and hoped to stay in Israel indefinitely. She was part-owner of a thriving internet cafe in Tel Aviv. One might think that her religiously-inspired Zionism combined with her relationship would predispose her to positive assessments of Israelis. Yet she had also been very poorly treated by two employers while caregiving. As an educated and articulate middle-class woman with an excellent understanding of her work rights, she had successfully gained compensation from one employer in the courts, and was pursuing a case against the second who had fired her to avoid paying for serious medical treatment that she required. Her atrocious and illegal treatment offset her positive ideological beliefs about Israel that she had derived from her religious community. This brought to the fore latent prejudices about Jews that led to contradictory expressions of belonging and not-belonging in Israel:

Joanna: I feel very, very, very comfortable [in Israe/]. [...] I know Israelis don't have patience, I know how to deal with them [laughs], you know, they shout, they scream immediately, like they have high blood pressure, they are...

Viv: Why?

Joanna: It's, you know, because they are dominating, they are confident that they are gifted, they are proud [...] Jewish people are the most wealthy in the world, so they are dominating, they want to dominate everything, I am used to their attitude now. ... am okay with it, because you know the Israelis, are, good fighters, and you know, I really believe in God, this is the land of God, he really won't let any....anything happen to this country.

For other participants, however, it was the difficulties of their life experiences during migration that led them to dissociate themselves from organized religion itself rather than condemn Israel or Israelis. Erlinda, a Catholic, had enduring belief in God but found institutional Christian worship increasingly implausible based on her personal experiences in Israel. In brief, Erlinda has been in Israel and the Occupied Territories for 21 years. After ten years of separation from his mother, Erlinda's son (then aged 17) joined her in Israel from the Philippines. But within a year, Erlinda went to America to work, seizing what seemed to be a once-in-a-lifetime opportunity for upward mobility. Devastatingly, her son back in Israel unexpectedly died from an illness shortly after, leaving two young children in Israel from two different mothers. Erlinda decided to return to Israel to become primary carer of one child whose mother disappeared. As Erlinda is a grandmother, rather than parent, there is no clear regularization path for the child and her in Israeli law. Now, mourning after her son's death, she regrets her past decisions, made in good faith: 
Because now, even now, to my family in the Philippines, I advise them not to [migrate]. Not to, especially if you have small children. Yes you are working here, you have a lot of money, you send it to the Philippines, but for me the most important thing is that the family are together, because ... what happened to me is really hard. (Erlinda)

Erlinda's life-story narrative is characterized by gendered strategies common to the context of Filipino migration: to support her son and escape her awful marriage with no divorce allowed in the Philippines, Erlinda went overseas to work..$^{55}$ Further, like so many Catholic Filipino arrivals in Israel, she was delighted at the time to be in the Holy Land. Today, shaped by her terrible loss, the sense of belonging she has developed in Israel is coloured through the everyday networks and ordinary life she has now led in Tel Aviv over more recent years that have kept her going. She is involved in a mother's group and is an active participant in joint Israeli/migrant worker anti-deportation actions. However, Erlinda no longer goes to church despite her enduring belief in God. In order to understand Erlinda's particular positionalities of religious belonging - and in this case, institutional not-belonging - the biographical intersections of her destroyed motherhood, her dashed hopes for class improvement, and her enduring uncertainty of migration status have shaped and changed her relationship to Catholicism:

Viv: Are you involved in the church?

Erlinda: Not so much! [laughs] for myself, before I was, but when these things happened, it makes me very...I don't blame, but...such a lot of questions... so before I was also a churchgoer. I believe in God but just to go to church like every week...not for me now.

\section{Conclusion}

The analysis of the narratives generated for this project go some way to pluralise the portrayal of the relationships between religion, gender and belonging amongst migrants in Israel. More broadly, the findings of this project suggest promising opportunities for future research examining gender and religion through intersectional frameworks to explore the dynamics between them and other sources of belonging. A variety of social locations in which Filipino migrants in Israel are located interact dynamically and relationally, including with religion and gender. In some times, places and spaces, the interplay between intersections of gender and other social locations leads to common experiences of religious belonging across certain clusters of participants, while leading to notable singularities of belonging in the lives of others. For example, while clear links emerge between threatened masculinities and religious belonging, these are crucially mediated by other factors, such as particular city locations and life-

${ }^{55}$ C. Tacoli, 'Migrating "For the Sake of the Family"? Gender, Life Course and IntraHousehold Relations amongst Filipino Migrants in Rome' in Philippine Sociological Review 44:1-4 (1996), 12-32. 
cycle stages. Most noticeably here, religious beliefs and practice, and gender amongst Filipino migrants in Israel are often deeply intertwined with people's sense of class belonging, brought to the foreground by the structures of the Philippine migration industry. Importantly, the vicissitudes of gendered experiences of migration have led a small number of women participants who do not take part in religious communities to express very ambivalent and complex forms of religious belonging and not-belonging. These nuanced positionalities found amongst Filipino men and women migrants in Israel show the value of openness to the intersections of multiple social locations that emerge in qualitative research in order to more richly represent both religious belonging, and the ways that religion and gender feed into other forms of belonging. 